University of Nebraska - Lincoln

DigitalCommons@University of Nebraska - Lincoln

Predicting the Probability of Detecting Organochlorine Pesticides And Polychlorinated Biphenyls in Stream Systems On The Basis Of Land Use in the Pacific Northwest, USA

\author{
Robert W. Black \\ U.S. Geological Survey, rwblack@usgs.gov \\ Alan L. Haggland \\ U.S. Geological Survey \\ Frank D. Voss \\ U.S. Geological Survey, fdvoss@usgs.gov
}

Follow this and additional works at: https://digitalcommons.unl.edu/usgsstaffpub

Black, Robert W.; Haggland, Alan L.; and Voss, Frank D., "Predicting the Probability of Detecting Organochlorine Pesticides And Polychlorinated Biphenyls in Stream Systems On The Basis Of Land Use in the Pacific Northwest, USA" (2000). USGS Staff -- Published Research. 536.

https://digitalcommons.unl.edu/usgsstaffpub/536

This Article is brought to you for free and open access by the US Geological Survey at DigitalCommons@University of Nebraska - Lincoln. It has been accepted for inclusion in USGS Staff -- Published Research by an authorized administrator of DigitalCommons@University of Nebraska - Lincoln. 


\title{
PREDICTING THE PROBABILITY OF DETECTING ORGANOCHLORINE PESTICIDES AND POLYCHLORINATED BIPHENYLS IN STREAM SYSTEMS ON THE BASIS OF LAND USE IN THE PACIFIC NORTHWEST, USA
}

\author{
Robert W. Black,* Alan L. Haggland, and Frank D. Voss \\ U.S. Geological Survey, Water Resources Division, 1201 Pacific Avenue, Suite 600, Tacoma, Washington 98402
}

(Received 4 January 1999; Accepted 5 August 1999)

\begin{abstract}
We analyzed streambed sediment and fish tissue (Cottus sp.) at 30 sites in the Puget Sound and Willamette basins in Washington and Oregon, USA, respectively, for organochlorine pesticides and polychlorinated biphenyls (PCBs). The study was designed to determine the concentrations of organochlorine pesticides and PCBs in fish tissue and sediment by land use within these basins and to develop an empirical relation between land use and the probability of detecting these compounds in fish tissue or sediment. We identified 14 organochlorines in fish tissue and sediment; three compounds were unique to either fish tissue or sediment samples. The highest number of organochlorines detected in both fish tissue and streambed sediment was at those sites located in watersheds dominated by urban land uses. Using logistic regression, we found a significant relation between percentage agriculture and urban land use and organochlorines in fish tissue. The results of this study indicate that organochlorine pesticides and PCBs are still found in fish tissues and bed sediments in these two basins. In addition, we produced statistically significant models capable of predicting the probability of detecting specific organochlorines in fish on the basis of land use. Although the presented models are specific to the two study basins, the modeling approach could be applied to other basins as well.
\end{abstract}

Keywords-Organochlorines Predictive models Fish tissue Streambed sediment Land use

\section{INTRODUCTION}

As part of the U.S. Geological Survey's National Water Quality Assessment (NAWQA) Program, organochlorine compounds and total polychlorinated biphenyls (PCBs) in the tissues of freshwater stream biota and in surficial streambed sediment are characterized across large hydrologic study areas or basins. Within a basin, sampling sites are located in streams that represent specific land uses. Prior to the NAWQA Program, studies designed to evaluate the impact of land use on organochlorine pesticides and total PCBs in tissues and sediment were often at a small spatial scale [1,2] and usually focused on a single land use or land practice. To date, only a few studies have examined the relation between large-scale land use practices and the presence of these compounds in biota and streambed sediment [3,4]. Furthermore, we are unaware of any studies that have developed models relating the presence or absence of organochlorine pesticides or total PCBs in biota or streambed sediment to land use at a regional level. The availability of such models would be valuable in planning future studies. In addition, models of this type would help managers identify those stream systems having the highest probability of organochlorines in aquatic biota or sediment. These models might also identify land use thresholds, that is, the land use percentage at which a particular contaminant has a statistically low or high probability of occurring in either fish tissue or sediment. Land use thresholds and their importance in impacting biological systems have been identified previously in the literature [4-6]. If the presence of organochlorines in fish tissue or streambed sediment can be fit to an $\mathrm{S}$-shaped curve or follows a nonlinear functional response in

* To whom correspondence may be addressed (rwblack@usgs.gov).

Any use of trade, product, or firm names is for descriptive purposes only and does not imply endorsement by the U.S. government. relation to land use, thresholds can be identified that may be less subjective in their interpretation than linear relations and that may facilitate management decisions.

Historically, organochlorines were used as pesticides in agricultural and urban settings, whereas PCBs were used in a number of industrial and commercial applications. Because of their resistance to degradation, susceptibility to large-scale transport, and extreme lipophilicity, the use and production of these compounds have been discontinued [7]. The abundance and persistence of organochlorine pesticides and PCBs in the environment are well established [8,9]. In addition, these compounds have been shown to have deleterious effects on aquatic and terrestrial organisms [10,11]. Although these compounds are often at nonlethal levels based on laboratory bioassays and in some cases below current body burden guidelines, they may still pose a biological risk at low concentrations. It has been shown that pesticide levels in the muscle tissues of aquatic organisms are directly correlated with levels found in their developing eggs [12]. Although the linkage between body burdens of organochlorines and PCBs and biological effects is not fully understood, body burdens are a measure of exposure. Recent evidence suggests that reproductive and developmental processes may be disrupted when organisms are exposed to nonlethal or low levels of organochlorine pesticides and PCBs [13-17]. As evidence accumulates on the biological consequences of exposure to low levels of pesticides, the need for methods capable of identifying aquatic populations at risk grows.

The presence of organochlorine pesticides and PCBs in the waters, fish tissue, and sediments of the Willamette basin of western Oregon is well established [18], whereas organochlorine and $\mathrm{PCB}$ conditions in the streams of the Puget Sound basin of western Washington are less well known [19]. Both the Willamette and the Puget Sound basins are being inves- 


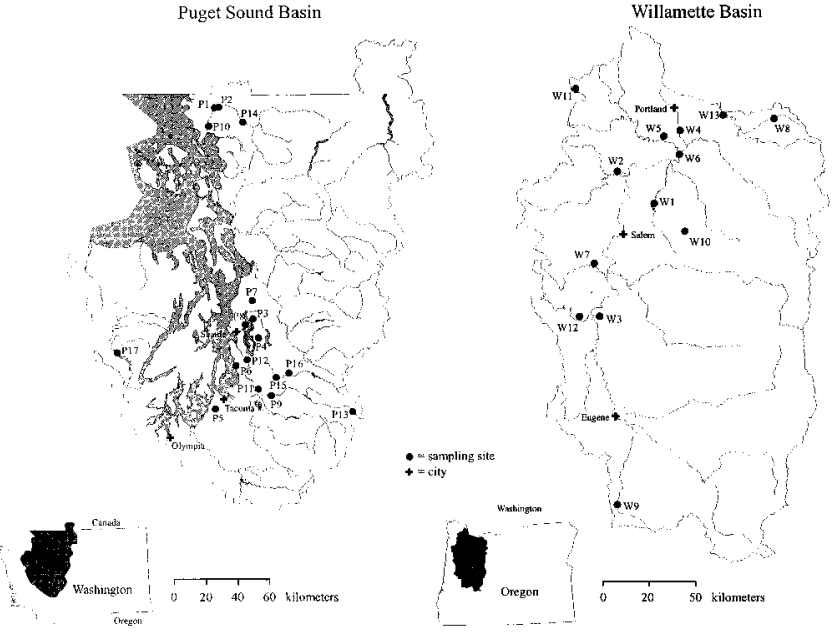

Fig. 1. Puget Sound and Willamette National Water Quality Assessment Study basins and sampling sites. The sampling site codes refer to those found in Table 1.

tigated as part of the NAWQA Program, and both are well known for their aquatic resources. However, the status of these resources is in jeopardy because of numerous anthropogenic and natural factors $[18,19]$. One such factor may be the presence of organochlorine pesticides and PCBs in the environment.

This study was designed to evaluate the occurrence and distribution of organochlorine pesticides and PCBs in fish tissue and bed sediment and their relation to land use in the Puget Sound and Willamette basins. In addition, using logistic regression, we identified those land use types most significantly correlated with the presence of these compounds in fish tissue and sediment. Finally, we used one of the logistic regression models developed in this study to evaluate the probability of detecting a specific organochlorine in fish tissue at a number sites throughout the Puget Sound basin.

\section{DESCRIPTION OF STUDY AREA}

The study area covers more than $35,000 \mathrm{~km}^{2}$ of the Puget Sound basin within Washington and $31,000 \mathrm{~km}^{2}$ of the Willamette basin within Oregon (Fig. 1). Fourteen watersheds drain $70 \%$ of the Puget Sound basin, and two watersheds, the Willamette and Sandy Rivers, drain the Willamette basin. Both the Puget Sound and Willamette basins are delimited by the Coast Range Ecoregion to the west [20]. Elevations in this ecoregion range from sea level to more than $600 \mathrm{~m}$, with peaks of more than $1,200 \mathrm{~m}$. Average annual precipitation ranges from 140 to $510 \mathrm{~cm}$, most of which falls during the winter $[18,19]$. The eastern boundary of both study basins is wholly or partly composed of the Cascade Ecoregion [20], which ranges from near sea level to more than $3,000 \mathrm{~m}$ and includes a number of glacially covered volcanoes. Precipitation within this ecoregion ranges from 125 to $250 \mathrm{~cm}$. The North Cascade Ecoregion also borders the Puget Sound basin on the northeast boundary. The North Cascade Ecoregion is similar to the Cascade Ecoregion but has less volcanic activity and is dominated by large topographic variations. The lowlands of the Puget Sound and Willamette basins are composed of the Puget Lowland and Willamette Valley Ecoregions, respectively. These low-lying ecoregions are filled with sediment, mainly of glacial, alluvial, and lacustrine origin. Precipitation in these two lowland ecoregions ranges from 35 to $125 \mathrm{~cm}$ annually.
Three land use or land cover types dominate both basins: urban, forest, and agriculture. A forest land cover dominates (78\%) the Puget Sound basin. Part of this land cover is within state, federal, and private forestry operations, and the remainder is either wilderness or national park lands. Forest land cover is found mainly within the Coast, Cascade, and North Cascade Ecoregions. About $8 \%$ of the basin is urban, and $6 \%$ is agriculture; these land uses are found mainly within the Puget Lowland Ecoregion adjacent to the Puget Sound (Fig. 1). However, rapid population growth in the basin is resulting in an increase in urban land use and a reduction in agricultural and forestry land uses [21]. The remaining land cover within the Puget Sound basin is composed of wetlands, rangeland, barren outcrops, and glaciers. Land use and land covers in the Willamette basin are similar to the Puget Sound basin. A forest land cover distributed between private and public ownership dominates about $70 \%$ of the Willamette basin. Agriculture represents $22 \%$ of the basin, and urban land use accounts for $6 \%$. As in the Puget Sound basin, urban land use is increasing rapidly, whereas agricultural and forestry land uses are declining. The remainder of the basin is composed of wetlands, rocky outcrops, and snow and ice.

\section{MATERIALS AND METHODS}

\section{Site selection and land use characterization}

We collected fish tissue samples and surficial streambed sediments at 30 sites located throughout the Puget Sound and Willamette basins (Fig. 1). Sampling site locations were chosen to represent dominant land use types found throughout both basins. Land use was determined using the Anderson Level II classification scheme from the U.S. Geological Survey 1:250,000-scale digital land use and land cover data set stored in the Geographic Information Retrieval and Analysis System [22]. Some urban areas were updated on the basis of 1990 census data [23]. We recorded the percentage land use in four land use categories for the basins upstream of each sampling site (Table 1). Each site was assigned to one of five summary land use categories on the basis of the percentage of each land use category within the basins. Two sites that had two land use percentages within 35 to $45 \%$ were identified as mixed land use. Two sites, Rock Creek at Cedar Falls and the North Fork Skokomish River, were characterized as reference sites. These two sites are located within a protected watershed and the Olympic National Park, respectively. The approach used in this study to assign sites to a summary land use category differs from that used in other ongoing studies in the Puget Sound basin [24]. MacCoy and Black [24] summarized land use on the basis of conditions adjacent to a sampling site rather than on the percentage land use throughout a basin. However, only three sites were categorized differently than those used in MacCoy and Black [24].

\section{Field collection}

To evaluate the presence and levels of organic compounds in the tissue of fish, various species of sculpin (Cottus sp.) were collected. Sculpin were selected as target taxa because of their benthic behavior and exposure to bottom sediments as well as their ubiquitous distribution throughout both study basins. Up to nine species of sculpin are found throughout the two basins [18,19]; all species are benthic predators with similar life histories $[25,26]$. We assumed that the similarities among species of sculpin would result in an equal probability 
Table 1. Sampling site names and basin land use percentages in the Puget Sound, Washington, and Willamette, Oregon, study basins

\begin{tabular}{|c|c|c|c|c|c|c|c|c|}
\hline \multirow{2}{*}{$\begin{array}{l}\text { Site } \\
\text { location }^{\text {a }}\end{array}$} & \multirow[b]{2}{*}{ Basin } & \multirow[b]{2}{*}{ Stream name } & \multirow{2}{*}{$\begin{array}{l}\text { Basin area } \\
\left(\mathrm{km}^{2}\right)\end{array}$} & \multirow{2}{*}{$\begin{array}{l}\text { Summary land } \\
\text { use category }\end{array}$} & \multicolumn{4}{|c|}{$\%$ Land use } \\
\hline & & & & & Urban & Agriculture & Forest & Other \\
\hline $\mathrm{P} 1$ & Puget & Bertrand Creek & 39 & Agriculture & 4 & 81 & 11 & 4 \\
\hline $\mathrm{P} 2$ & Puget & Fishtrap Creek & 31 & Agriculture & 11 & 87 & 2 & 0 \\
\hline W1 & Willamette & Zollner Creek & 39 & Agriculture & 1 & 99 & 0 & 0 \\
\hline W2 & Willamette & Palmer Creek & 92 & Agriculture & 1 & 85 & 10 & 0 \\
\hline W3 & Willamette & Muddy Creek & 377 & Agriculture & 2 & 47 & 27 & 24 \\
\hline P3 & Puget & Juanita Creek & 16 & Urban & 91 & 0 & 9 & 1 \\
\hline P4 & Puget & W.B. Kelsey Creek & 25 & Urban & 88 & 0 & 11 & 1 \\
\hline P5 & Puget & Leach Creek & 13 & Urban & 68 & 0 & 28 & 4 \\
\hline P6 & Puget & Miller Creek & 22 & Urban & 94 & 0 & 5 & 1 \\
\hline P7 & Puget & North Creek & 24 & Urban & 59 & 3 & 35 & 3 \\
\hline P8 & Puget & Thornton Creek & 31 & Urban & 99 & 0 & 1 & 0 \\
\hline W4 & Willamette & Johnson Creek & 128 & Urban & 52 & 26 & 20 & 2 \\
\hline W5 & Willamette & Fanno Creek & 80 & Urban & 70 & 14 & 12 & 4 \\
\hline P9 & Puget & Newaukum Creek & 71 & Mixed & 20 & 39 & 40 & 1 \\
\hline W6 & Willamette & Tualatin River & 1,832 & Mixed & 21 & 36 & 41 & 2 \\
\hline P10 & Puget & Nooksack River (Brennan) & 1,898 & Forest & 2 & 13 & 76 & 9 \\
\hline P11 & Puget & Big Soos Creek & 173 & Forest & 35 & 4 & 58 & 3 \\
\hline $\mathrm{P} 12$ & Puget & Duwamish River & 1,194 & Forest & 16 & 8 & 74 & 2 \\
\hline P13 & Puget & Green River & 43 & Forest & 0 & 0 & 100 & 0 \\
\hline P14 & Puget & Nooksack River (Cedarville) & 1,523 & Forest & 1 & 1 & 88 & 10 \\
\hline $\mathrm{P} 15$ & Puget & Rock Creek (Maple Valley) & 33 & Forest & 10 & 0 & 89 & 1 \\
\hline W7 & Willamette, & Luckiamute River & 615 & Forest & 1 & 19 & 80 & 0 \\
\hline W8 & Willamette & Fir Creek & 15 & Forest & 0 & 0 & 100 & 0 \\
\hline W9 & Willamette & Willamette River & 184 & Forest & 1 & 1 & 94 & 4 \\
\hline W10 & Willamette & Little Abiqua Creek & 25 & Forest & 1 & 3 & 96 & 0 \\
\hline W11 & Willamette & Gales Creek & 18 & Forest & 0 & 0 & 100 & 0 \\
\hline W12 & Willamette & Marys River & 392 & Forest & 4 & 10 & 84 & 2 \\
\hline W13 & Willamette & Sandy River & 1,253 & Forest & 2 & 1 & 94 & 3 \\
\hline P16 & Puget & Rock Creek (Cedar Falls) & 9 & Reference & 0 & 0 & 100 & 0 \\
\hline P17 & Puget & N.F. Skokomish River & 141 & Reference & 0 & 0 & 91 & 9 \\
\hline
\end{tabular}

a Site location refers to codes used to identify each sampling site in Figure 1.

b Summary land use categories are based on the most abundant land use within each sampling site basin. Those sites with two land uses within 35 to $45 \%$ were categorized as mixed.

of exposure to organic compounds found in the sediments and the water column at all sampling sites.

Fish were collected using a battery-powered backpack shocker (Smith-Root, Vancouver, WA, USA; Model 12) and transferred in stainless-steel holding containers to an enclosed mobile laboratory. Each fish was rinsed with native water and weighed $(\mathrm{g})$ and measured for total length $(\mathrm{mm})$. At each site, a minimum of five whole sculpin of similar length and weight were composited for analysis. For each composite, fish were individually wrapped in aluminum foil (dull side toward the fish), combined together in a plastic bag, labeled, and stored on dry ice before shipment to the U.S. Geological Survey's National Water Quality Laboratory in Arvada, Colorado, USA. Once at the lab, all samples were stored at $-15^{\circ} \mathrm{C}$. Additional details on tissue sampling procedures are in Crawford and Luoma [27].

Five to 10 samples of surficial streambed sediment (upper $2 \mathrm{~cm}$ ) were collected from depositional zones along each study reach and composited for organic compound analysis according to guidelines established by Shelton and Capel [28]. Individual depositional samples were collected from multiple microhabitats, which included pools, riffles, and runs. A composite sample of sediment from multiple habitat types within each study reach was collected for analysis because it provides the best assessment of organic compounds in a stream compared to a single sample. Samples were collected with a glass beaker during low-flow conditions. Each sample was homogenized in a glass bowl with a Teflon ${ }^{\circledR}$ spatula. The homogenized sample was passed through a $2.0-\mathrm{mm}$ stainless-steel sieve and collected in a glass sample jar with a Teflon (PTEE) lined lid. Each jar was labeled, packed in wet ice, and shipped by overnight carrier to the National Water Quality Laboratory. Once at the lab, excess water above the sediment layer was carefully decanted, and each sample was stored at $-15^{\circ} \mathrm{C}$. Before and after visiting each sampling site, all sampling equipment was washed and soaked in $0.2 \%$ phosphate-free detergent and rinsed with deionized water and residue-grade methanol. After the final rinse with methanol, each piece of sampling equipment was wrapped in aluminum foil and stored in a plastic container.

\section{Laboratory analysis}

Sediment and tissue samples were analyzed for organic compounds and total PCBs at the National Water Quality Laboratory. Whole-fish composites for each sampling site were homogenized at the lab. Samples were extracted for a minimum of $8 \mathrm{~h}$ with dichloromethane using a Soxhlet extractor. Extracts were cleaned using gel-permeation chromatography and fractionated using alumina/silica adsorption chromatography. Extracts were analyzed using a programmed dual capillary-column gas chromatography with electron-capture detection. Total PCB concentrations were based on a comparison of PCBs in the collected samples to standards containing a 1: 1:1 mixture of Aroclor ${ }^{\circledR} 1242,1254$, and 1260 (Monsanto, St. Louis, MO, USA). Minimum reporting levels and a list of analytes are shown in Table 2. The minimum reporting levels for each compound were set above the minimum detection limits to reduce the probability of a false-positive detection to 
Table 2. Organochlorines and total PCBs analyzed in whole sculpin tissue ( $\mu \mathrm{g} / \mathrm{kg}$, wet wt) and streambed sediment ( $\mu \mathrm{g} / \mathrm{kg}_{\mathrm{oc}}$, dry wt) composites, collected in the Puget Sound and Willamette basins

\begin{tabular}{|c|c|c|c|c|c|}
\hline \multirow[b]{2}{*}{ Compound } & \multicolumn{2}{|c|}{ Method reporting limit } & \multirow[b]{2}{*}{ Compound } & \multicolumn{2}{|c|}{ Method reporting limit } \\
\hline & Tissue & Sediment & & Tissue & Sediment \\
\hline Aldrin & 5.0 & 1.0 & Heptachlor & 5.0 & 1.0 \\
\hline cis-Chlordane & 5.0 & 1.0 & Heptachlor epoxide & 5.0 & 1.0 \\
\hline trans-Chlordane & 5.0 & 1.0 & Hexachlorobenzene & 5.0 & 1.0 \\
\hline Chlorneb & - & 5.0 & Isodrin & - & 1.0 \\
\hline DCPA & 5.0 & 5.0 & $o, p^{\prime}$-Methoxychlor & 5.0 & 5.0 \\
\hline$o, p^{\prime}-\mathrm{DDD}$ & 5.0 & 1.0 & $p, p^{\prime}$-Methoxychlor & 5.0 & 5.0 \\
\hline$p, p^{\prime}-\mathrm{DDD}$ & 5.0 & 1.0 & Mirex & 5.0 & 1.0 \\
\hline$o, p^{\prime}-\mathrm{DDE}$ & 5.0 & 1.0 & cis-Nonachlor & 5.0 & 1.0 \\
\hline$p, p^{\prime}-\mathrm{DDE}$ & 5.0 & 1.0 & trans-Nonachlor & 5.0 & 1.0 \\
\hline$o, p^{\prime}-\mathrm{DDT}$ & 5.0 & 2.0 & Oxychlordane & 5.0 & 1.0 \\
\hline$p, p^{\prime}$-DDT & 5.0 & 2.0 & Pentachloranisole & 5.0 & 1.0 \\
\hline Dieldrin & 5.0 & 1.0 & cis-Permethrin & - & 5.0 \\
\hline Endosulfan & - & 1.0 & trans-Permethrin & - & 5.0 \\
\hline Endrin & 5.0 & 2.0 & Toxaphene & 200.0 & 200.0 \\
\hline$\gamma-\mathrm{HCH}$ (lindane) & 5.0 & 1.0 & Total PCB & 50.0 & 50.0 \\
\hline
\end{tabular}

less than $1 \%$. The minimum detection limits for each compound were determined on the basis of the methods outlined by the U.S. Environmental Protection Agency (U.S. EPA) [29]. Sample preparation and analysis details and minimum reporting level determinations are provided in Foreman et al. [30] and Leiker et al. [31].

Laboratory quality assurance samples were used to estimate the quality of the analytical data, to determine the need for internal laboratory corrective action, and to interpret results after corrective action procedures were implemented. Laboratory quality control included lab blanks, surrogate recovery spikes, and reagent spikes. Lab blanks help identify the presence of contamination during preparation and analysis in the laboratory. Surrogate recovery spikes help verify analytical method performance by recovery of surrogate compounds in a particular matrix. Reagent spikes help verify the accuracy of an analytical method for each set of samples. On the basis of laboratory quality assurance procedures, no contamination of samples was observed while at the lab, and analytical methods were at acceptable levels for all samples.

\section{Data analysis}

A one-way analysis of variance was used to determine whether a significant difference existed in the total number of organochlorine pesticides and total PCBs detected by summary land use categories identified in Table 1. Logistic regression was used to determine those land use categories and their coefficient values that best predicted the probability of detecting specific organochlorine pesticides or total PCBs in fish tissue or streambed sediment. Logistic regression, used extensively in the medical sciences, has more recently been used in the environmental field to detect those factors responsible for a binary outcome [32,33]. Although similar to linear regression, logistic regression requires binary dependent data rather than continuous data. To convert continuous data on concentrations of specific individual organochlorine compounds or total PCBs to binary data, we assigned a value of one to all sites where that compound was measured above the minimum reporting level in either tissue or sediment for that site. Sites where that compound was not detected were assigned a value of zero. The form of the logistic regression model is as follows:

$$
P=\frac{\exp \left(b_{0}+b_{1} X_{1}+b_{2} X_{2}+\cdots b_{n} X_{n}\right)}{1+\exp \left(b_{0}+b_{1} X_{1}+b_{2} X_{2}+\cdots b_{n} X_{n}\right)}
$$

where $P=$ the probability that a specific organochlorine compound or total PCBs is present in a detectable concentration, $X_{n}=$ a vector of independent explanatory variable values such as percentage urban or agricultural land use, $b_{0}=$ an intercept parameter, and $b_{n}=$ a slope coefficient value associated with a specific explanatory variable.

A more detailed discussion of logistic regression can be found in Hosmer and Lemeshow [34] and Helsel and Hirsch [35]. Using an iterative procedure, the SYSTAT $^{\circledR}$ statistical analysis computer software program [36] calculates values for $b_{0}$ and all $b_{n}$ values that maximize the likelihood function, $l$

$$
l=\sum_{i=1}^{m}\left[\left(y_{i} \ln P_{i}\right)+\left(1-y_{i}\right) \ln \left(1-P_{i}\right)\right]
$$

where $m=$ the number of observations in the data set and $y_{\mathrm{i}}$ $=$ the outcome variable that is set to 1 when a specific organochlorine or total PCBs in fish tissue or streambed sediment is present.

We calibrated four logistic models for each compound that had five or more detections. Each model was based on a different set of independent explanatory variables, which included percentage urban land use, percentage agricultural land use, percentage urban land use and percentage agricultural land use (two-variable model), and the summation of percentage urban and percentage agriculture land use. Land use percentages from Table 1 were used as independent variables in all models.

The evaluation of a logistic regression equation is similar to that of linear regression. We used a $t$ ratio to evaluate the significance of coefficient estimates in all models. To test the hypothesis that all coefficients except the intercept are zero, we used an overall likelihood-ratio test, which can be interpreted much like an $F$ test in linear regression. An adjusted generalized coefficient of determination $\left(R^{2}\right)$ was also used to evaluate each model [37]. The adjusted $R^{2}$ used in this study is consistent with classical adjusted $R^{2}$ values used in linear regression. It is asymptotically independent of sample size, ranges between zero and one, and can be interpreted as the proportion of explained variation.

To statistically compare simple (one independent variable) 
and complex (two independent variables) nested models for each compound, we calculated a partial likelihood ratio as follows:

$$
l r=2 \cdot\left(l_{c}-l_{s}\right)
$$

where $l_{c}=$ the $\log$ likelihood of the complex model (i.e., percentage urban land use and percentage agricultural land use) and $l_{s}=$ the $\log$ likelihood of the simple model (i.e., percentage urban land use).

The partial likelihood ratio is approximated by a chi-square distribution with the number of degrees of freedom equal to the number of additional independent variables in the more complex model [35].

To compare nonnested logistic regression models (i.e., percentage agricultural land use versus the summation of the percentage urban and percentage agricultural land use), Akaike's Information Criteria (AIC) was calculated for each model as follows:

$$
\mathrm{AIC}=-(l+k)
$$

where $l=$ the $\log$ likelihood and $k=$ the number of independent variables.

The AIC includes both a measure of model error $(l)$ and a penalty for too many explanatory variables $(k)$. Better models have a lower AIC value [34,35]. This test assumes that both models use the same set of observations.

\section{RESULTS AND DISCUSSION}

Occurrence of organochlorine pesticides and PCBs in bed sediment and sculpin tissue

Of the 30 organic compounds analyzed, 14 were detected in both tissue and sediment samples collected at the 30 sampling sites (Tables 3 and 4). Three detected compounds were unique to a particular medium. These compounds were heptachlor epoxide, oxychlordane, and pentachloranisole in tissues and endosulfan, $o, p^{\prime}$-dichlorodiphenyldichloroethane (DDD), and $p, p^{\prime}$-methoxychlor in sediment (endosulfan was analyzed only in sediment).

The concentrations of organochlorine pesticides and total PCBs observed in sculpin tissues were generally similar to those observed in other large-scale studies [8]. With a few exceptions, concentrations of most compounds in tissue samples were below the national compound-specific geometric means observed in 1984 by Schmitt et al. [8]. Those compounds that exceeded the 1984 geometric means included oxychlordane, cis-chlordane, and total PCBs at one site each; trans-nonachlor at two sites; and $p, p^{\prime}$-DDT at three sites. Total PCB and $p, p^{\prime}$-DDT concentrations in tissue samples collected from the Puget Sound basin were comparable to earlier studies conducted in the basin [19]. Contaminant concentrations observed in tissues collected in the Willamette basin were also comparable to levels observed in previous studies in that basin [18,38].

Generally, compounds detected in sculpin tissue were also detected in streambed sediments. The exception to this observation was the three compounds that were detected only in either tissue or sediment samples. For those compounds detected in both media, the frequency of detection was always higher in fish tissue (Fig. 2). The most commonly detected compound in both tissue and sediment samples was $p, p^{\prime}$-dichlorodiphenyldichloroethylene (DDE), which was detected at more than $50 \%$ of the sites in sculpin tissue and $30 \%$ of the sites in streambed sediment. Dieldrin, trans-nonachlor, and $p, p^{\prime}$-DDT were detected in sculpin tissues at 33, 37, and $30 \%$ of the sites, respectively. The frequency of detections in this study is similar to those observed in other national studies [7,8]. In the Schmitt et al. [8] and the U.S. EPA [7] studies, $p, p^{\prime}$-DDE was the most commonly detected organochlorine in fish tissue. Similar to our study, dieldrin, cis- and trans-chlordane and nonachlor, and $p, p^{\prime}$-DDT were also frequently detected in the Schmitt et al. [8] and the U.S. EPA [7] studies.

The largest number of organochlorine pesticides and total PCBs detected in both sculpin tissue and streambed sediments occurred at the urban sites (Fig. 3). In addition, concentrations of all compounds found in tissues and most compounds found in sediments were highest at the urban sites (Tables 3 and 4). No organochlorine pesticides or PCBs were detected at either of the reference sites in either the tissue or the sediment samples. At our forest practice (forested land use) sites, $p, p^{\prime}$-DDT and $p, p^{\prime}$-DDE were the only two compounds detected in either tissues or sediment (Tables 3 and 4). The number of compounds detected in sculpin tissue was significantly higher at the agriculture or urban sites than at the forested and reference sites (analysis of variance, $F=22.4, p<0.001$ ). However, no significant difference was observed in the number of compounds detected in sediment among land use categories. Morris et al. [39] suggest that the temporal and spatial variability in the delivery and sorting of the bed material of rapidly flowing rivers may make it difficult to assess organochlorine compounds in this medium. In addition, the variable composition of sediments entering stream systems throughout the Puget Sound and Willamette basins can affect the rate of sorption and desorption [40]. Conversely, aquatic biota are extremely efficient at accumulating periodically delivered organochlorine pesticides and PCBs [27,41].

\section{Predicting the probability of detecting organochlorine pesticides and PCBs in sculpin tissue}

To determine the probability of detecting specific organochlorine pesticides or total PCBs in sculpin tissue or streambed sediments, we used logistic regression to create models relating percentage land use type and the detection or nondetection of these compounds. The following independent explanatory variables were considered for each compound with five or more detections: percentage urban land use, percentage agricultural land use, percentage urban land use and percentage agricultural land use, and the summation of percentage urban and percentage agricultural land use. Table 5 shows regression coefficients and statistics for all significant one- and two-variable models generated for predicting the probability of detecting an organochlorine compound or total PCBs in sculpin tissue. Method reporting limits were consistent for all samples used in each of the presented models.

As expected, a positive relation was found between the probability of detecting organochlorine pesticides and total PCBs in sculpin tissue and the percentages of various land uses (Fig. 4). In all cases except for $p, p^{\prime}$-DDD, the positive relations were significant. The best models for predicting the probability of detecting dieldrin-cis- and trans-nonachlor, $p, p^{\prime}$-DDE, $p, p^{\prime}$-DDT, and cis- and trans-chlordane-in sculpin tissue on the basis of AIC comparisons all included the summation of the percentage urban and percentage agricultural land use as the independent explanatory variable (Table 5). The $R^{2}$ values for these seven models ranged from 0.41 for trans-chlordane to 0.81 for dieldrin (Table 5). The strength of the logistic models can also be seen in Figure 4. Those models 


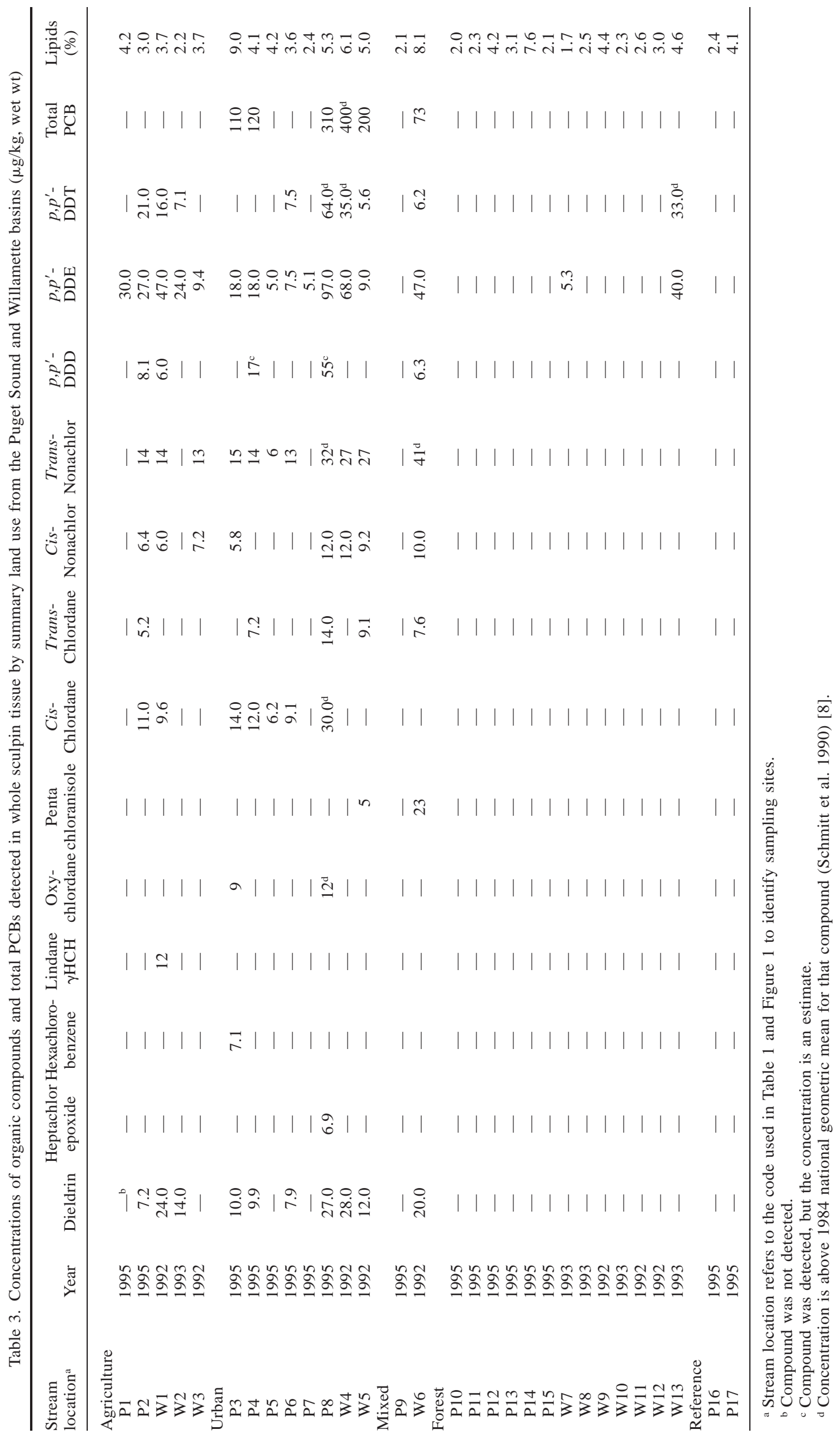




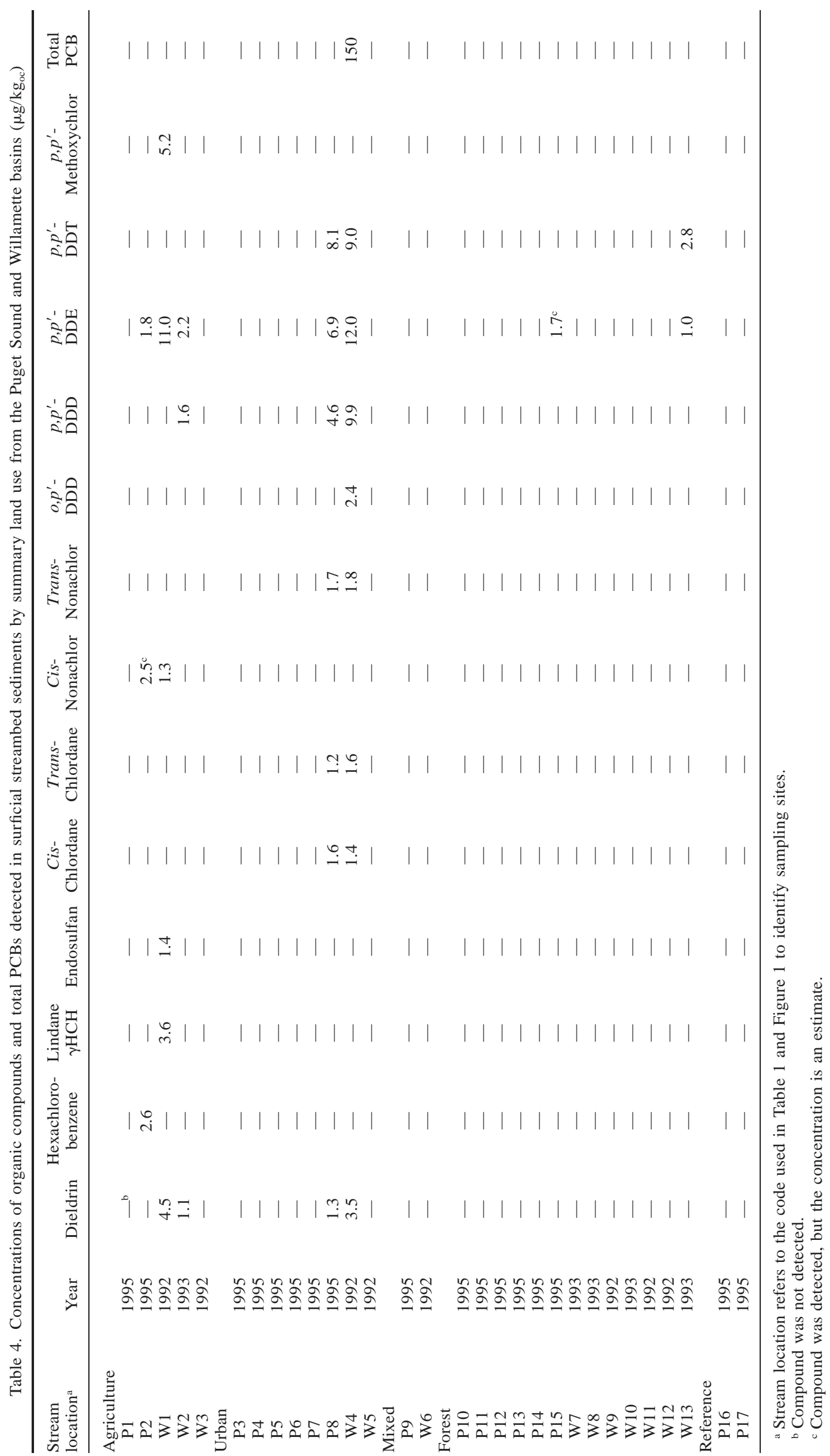




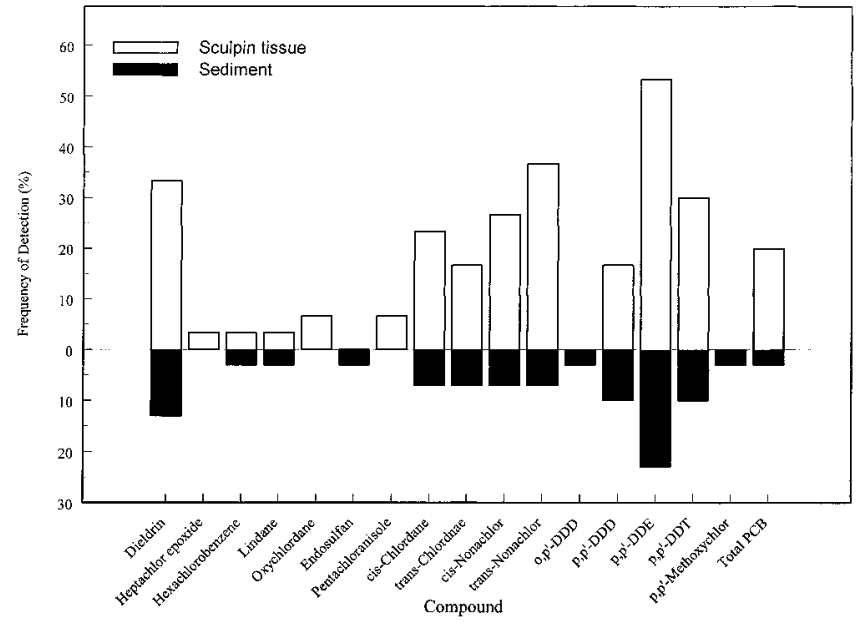

Fig. 2. Detection frequency of organochlorine pesticides and total polychlorinated biphenyls in whole sculpin tissue and streambed sediment in the Puget Sound and Willamette Study basins.

with a more pronounced S shape (e.g., dieldrin) have a higher $R^{2}$ value and have greater predictive power. The $\mathrm{S}$ shape of the logistic function is also ideally suited for examining breakpoints or thresholds in land use characteristics that result in specific probabilities of a nondetection or detection of various compounds in sculpin tissue. For example, the dieldrin model exhibits distinct land use threshold values at 46 and $71 \%$ total urban and agricultural land use (Fig. 4). These two thresholds correspond to a 5 and $50 \%$ probability of detecting dieldrin in sculpin tissue. The $50 \%$ threshold of detecting dieldrin in sculpin tissue identifies the steepest location on the logistic function or the point at which the probability of detecting dieldrin is changing most rapidly. Both of these threshold values may be of particular value to managers and scientists interested and working in a basin. Generally, for each compound, specific land uses above $60 \%$ resulted in a $50 \%$ probability of detecting or not detecting that compound in whole sculpin tissue (Fig. 4).
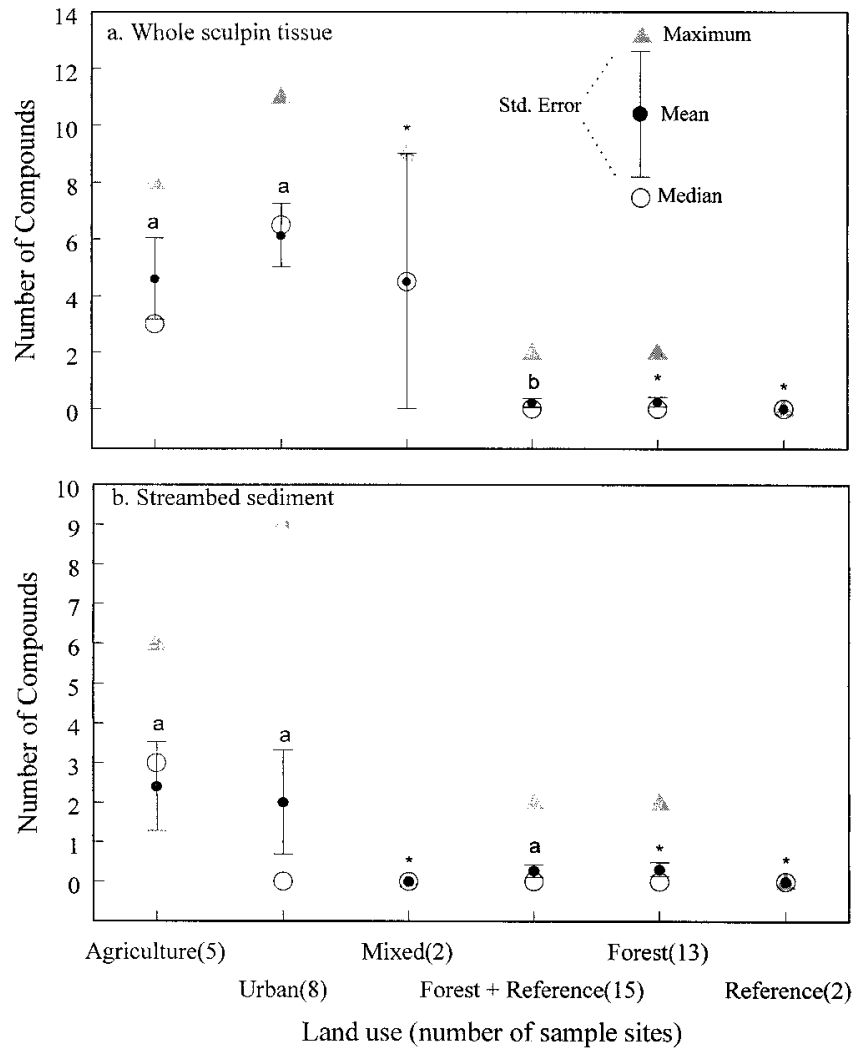

Fig. 3. Mean (1 SE) and median number of compounds detected in whole-sculpin tissue and streambed sediment by summary land use type in the Puget Sound and Willamette study basins. Land use types with different letters above their standard error bars are significantly different $(p<0.05)$. Land use type with an asterisk $(*)$ above their standard error bars were not included in the analysis of variance.

A number of outliers can be seen in Figure 4. Ideally, all the nondetections (n) should occur on the lower-left side of each graph, whereas all the detections (d) should occur on the upper-right side of each graph. Data collected at the Bertrand

Table 5. Logistic regression results by compound for tissue models ${ }^{\mathrm{a}}$

\begin{tabular}{|c|c|c|c|c|c|c|c|c|}
\hline Compound & & $\begin{array}{l}\text { Intercept } \\
\text { coefficient }\end{array}$ & $\begin{array}{l}\% \text { Urban } \\
\text { coefficient }\end{array}$ & $\begin{array}{c}\% \text { Agriculture } \\
\text { coefficient }\end{array}$ & $\begin{array}{c}\text { Sum of } \% \text { urban } \\
+\% \text { agriculture } \\
\text { coefficient }\end{array}$ & Log likelihood & $\begin{array}{c}\text { Overall } \\
\text { likelihood ratio } \\
(p \text { value })\end{array}$ & $R^{2}$ \\
\hline \multirow{2}{*}{ Dieldrin } & & -1.84 & 4.07 & & & -13.95 & 0.001 & 0.40 \\
\hline & b & -8.41 & & & 11.87 & -5.86 & $<0.001$ & 0.81 \\
\hline \multirow{2}{*}{ cis-Nonachlor } & & -4.12 & 4.84 & 5.62 & & -11.09 & 0.002 & 0.50 \\
\hline & b & -4.10 & & & 5.12 & -11.21 & $<0.001$ & 0.49 \\
\hline trans-Nonachlor & b & -4.52 & & & 7.03 & -9.07 & $<0.001$ & 0.69 \\
\hline \multirow[t]{2}{*}{$p, p^{\prime}-\mathrm{DDE}$} & & -2.63 & 6.73 & 7.59 & & -8.98 & $<0.001$ & 0.72 \\
\hline & b & -2.61 & & & 7.03 & -9.00 & $<0.001$ & 0.72 \\
\hline \multirow{3}{*}{$p, p^{\prime}-\mathrm{DDT}$} & & -3.29 & 3.82 & 5.13 & & -12.48 & 0.003 & 0.45 \\
\hline & & -1.52 & & 3.05 & & -15.74 & 0.020 & 0.22 \\
\hline & b & -3.24 & & & 4.26 & -12.81 & 0.001 & 0.44 \\
\hline cis-Chlordane & & -2.86 & 4.67 & & & -10.36 & 0.001 & 0.49 \\
\hline
\end{tabular}

a All coefficients are significant at the 0.05 level. Only those models with significant coefficients are included.

${ }^{\mathrm{b}}$ Indicates the best model for predicting the probability of detecting each specific compound based on the procedures described in the Materials and Methods section. 

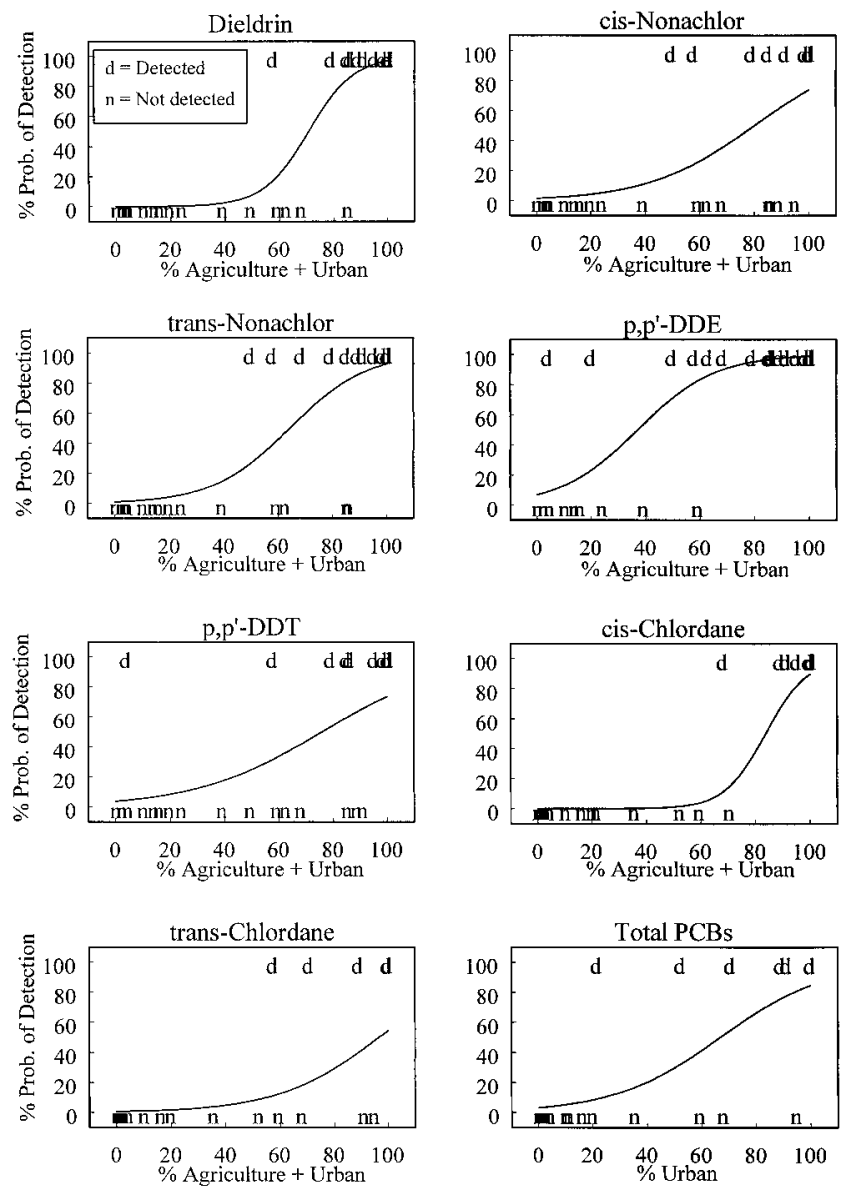

Fig. 4. Logistic regression model results for whole-sculpin tissue and raw data by compound for the Puget Sound and Willamette study basins. The solid line in each graph represents the probability of detecting a specific compound on the basis of the percentage of a specific land use or combination of land uses. Each line was generated from Equation 1 and from coefficients in Table 5.

Creek site were consistently outliers. Organochlorines were rarely observed in the tissues of sculpin found at this site (Table $3)$. Although the watershed upstream of this sight was dominated by agricultural land use, the immediate area surrounding the sampling site was dense forest with a well-established riparian zone. It is possible that the riparian zone around the sampling site helped buffer the input of contaminants. The Sandy River site is dominated by forested land use, but tissue samples collected at this site had detectable levels of $p, p^{\prime}$ DDE and $p, p^{\prime}$-DDT (Table 3). Like the Bertrand Creek site, local factors may be the reason for the organochlorine detection pattern observed at this site. In either case, we do not have enough information to justify discarding these outliers or any others, but we should be aware of them.

Historically, dieldrin, DDT, and chlordane were used extensively in both agricultural and urban settings to control insects [7]. Thus, it is not surprising that knowing the percentage of both of these land uses is useful for predicting the presence of these compounds in sculpin tissue. The probability of detecting cis- and trans-nonachlor and $p, p^{\prime}$-DDE in sculpin was also statistically related to the summation of percentage urban and percentage agricultural land use (Table 5). Nonachlor, cis and trans, is an impurity in the insecticide chlordane and heptachlor [7], whereas $p, p^{\prime}$-DDE is a breakdown product of DDT. It can be speculated that the relations between de- tecting these compounds in sculpin tissue and the summation of percentage urban and percentage agricultural land use is the result of historical uses of chlordane, heptachlor, and DDT in both of these land uses. Although none of these compounds is currently being used in either basin, it is likely that the presence of these compounds in sculpin is the result of sediment erosion originating from either urban or agricultural land uses. It has been shown that sediments located in areas with specific land uses can serve as reservoirs for organochlorines bound to these sediments [42]. When sediment erosion occurs, these contaminated soils are transported into aquatic systems $[43,44]$. Once in the stream environment, benthic organisms such as sculpin are exposed to the contaminated sediments. Although sediment may be the main source of organochlorines in aquatic systems, atmospheric inputs may also contribute small amounts [45].

Total PCBs was the only compound that was significantly correlated exclusively with the percentage of urban land use (Fig. 4 and Table 5). The addition of percentage agricultural land use produced a higher $R^{2}$ value, but the coefficient estimate for percentage agriculture was not a significant predictor of the presence or absence of total PCBs in sculpin tissue. On the basis of the $R^{2}$ value, the logistic model for total PCBs showed a high correlation between percentage urban land use and the probability of detecting this compound in sculpin tissue (Table 5). The statistically significant relationship between percentage urban land use and the probability of detecting PCBs in fish tissue was not surprising. It was one of only four compounds detected in either sculpin tissue or sediment that occurred exclusively in areas dominated by urban land use (Tables 3 and 4). The PCBs were used mainly in industrial settings as a dielectric fluid, lubricant, and solvent.

\section{Regression analysis results for detecting organochlorine pesticides and PCBs in streambed sediment}

Of the four independent explanatory variables considered, none produced a model capable of significantly predicting the probability of detecting organochlorine pesticides or total PCBs in streambed sediment. It has been suggested that onetime sampling of streambed sediments may be an ineffective way of sampling organochlorines and possibly PCBs [4,39]. Contaminated streambed sediments can be scoured and continually resorted with cleaner sediments, resulting in a possible dilution of more contaminated sediments. The continual and variable nature of sediment loading, resorting, and dilution may explain why we detected so few contaminants at each of our sediment sampling sites and why we were unable to produce any significant logistic models.

\section{Fish tissue (sculpin) vulnerability}

On the basis of the models presented in this study and the abundance of streams flowing through watersheds dominated by urban and agricultural land uses, it is likely that sculpin in many of the low-elevation streams in the Puget Sound and Willamette basins are contaminated with organochlorine pesticides or PCBs. As an example, Figure 5 displays the probability of detecting trans-nonachlor in sculpin at a number of sites throughout the Puget Sound basin. Although we used trans-nonachlor for this example, similar trends would be observed for all compounds with significant logistic models. The probabilities presented in Figure 5 were generated by calculating the percentage of urban and agricultural land use upstream of each site and then calculating the probability of 


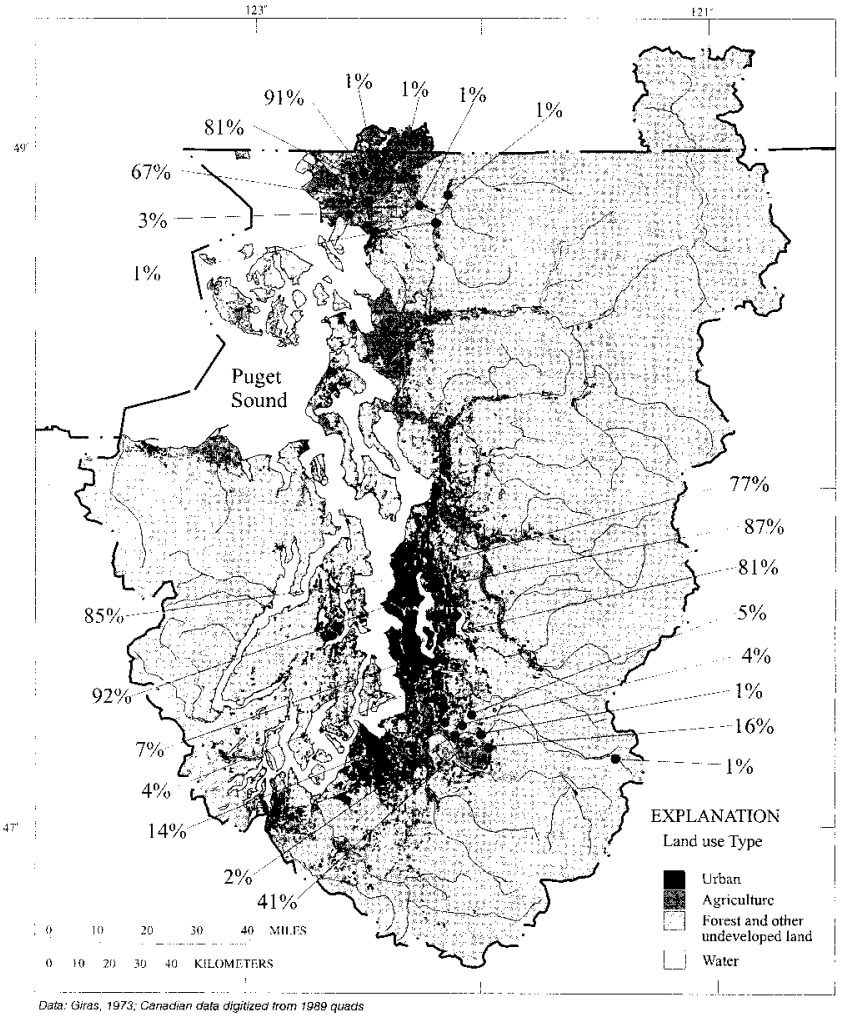

Fig. 5. Land use and model output depicting the probability of detecting trans-nonachlor at selected sites in the Puget Sound basin.

detecting trans-nonachlor using the coefficients in Table 5 and Equation 1. It is apparent from Figure 5 that sculpin in smaller streams originating in the Puget Sound lowlands have a high probability of having trans-nonachlor in their tissue. Many of the small Puget Sound lowland streams drain watersheds dominated by urban or agricultural land uses. Sculpin in streams located at higher elevations or in low-elevation streams located in watersheds dominated by forested land use have a much lower probability. Sculpin found at the mouths of large rivers draining into the Puget Sound have a very low probability of having trans-nonachlor in their tissue. Although many of the large rivers draining into the Puget Sound pass through urban and industrial areas, forested land use dominate their watersheds. We suspect that the abundance of high-quality water originating from the headwaters of many of the larger rivers [21] helps dilute any potential contaminants originating from these urban areas, thereby reducing the probability of detecting contaminants in sculpin. Maps of this type, and the models used to generate them, should help resource managers and scientists identify those streams most likely to have organochlorine pesticides and PCBs in fish tissue.

Although the models developed to predict the probability of detecting organochlorine pesticides or PCBs in fish tissue on the basis of land use percentages were statistically significant, they were developed on the basis of composite samples of a single fish species from streams located in two basins with similar but unique characteristics. The results of the logistic regression modeling are also dependent on laboratory detection limits; higher or lower limits would alter the models. Finally, we were unable to validate our models, given the small size of the data set. Given the limitations under which the models in this study were developed, these models should be used with caution. Nevertheless, they may provide a means by which resource managers or scientists can screen or assess the probability of detecting contaminants in fish tissues at various locations with similar basin sizes within the Puget Sound and Willamette basins.

\section{CONCLUSIONS}

Although the use of organochlorine pesticides and PCBs has been discontinued in the United States, our study indicates that they are still found in aquatic systems at levels that may be of concern to aquatic organisms. In some cases, compounds observed in fish tissue in our study were above median concentrations observed in other studies conducted at a national scale [8]. Our study also identified a significant relation between land use and the detections of organochlorine pesticides and PCBs in the tissue of sculpin. Logistic regression models were developed out of these relations to predict the probability of detecting organochlorine pesticides or PCBs in sculpin tissue on the basis of land use percentages. Although we are aware of the limitations of these models, we believe that the models and approach used to create them may be of benefit to resource managers and scientists. A similar relation was not observed for streambed sediments. We suspect that continual scouring and resorting of streambed sediments and possible dilution of the more contaminated sediments with clean sediment may be why we were unable to identify any relations with land use. Our findings suggest that future studies should continue to evaluate the relation between land use and the detection of organochlorine pesticides and PCBs in aquatic organisms.

Acknowledgement-This study was funded as part of the U.S. Geological Survey's National Water Quality Assessment Program. The authors would like to thank the Puget Sound and Willamette Basin NAWQA study unit teams for their assistance in the collection of the data and preparation of the information presented in this paper. The authors would also like to thank M.D. Munn, D. Mueller, A.J. Tesoriero, W.T. Foreman, and two anonymous reviewers for all their valuable input in the preparation of this paper.

\section{REFERENCES}

1. Miskiewicz AG, Gibbs PJ. 1994. Organochlorine pesticides and hexachlorobenzene in tissues of fish and invertebrates caught near a sewage outfall. Environ Pollut 25:269-277.

2. Chevreuil M, Granier L, Carru A. 1995. Relationship between biological parameters and bioaccumulation of some organochlorines (pesticides, PCB) by fishes in the River Seine (France). Water Air Soil Pollut 81:107-120.

3. Truhlar JF, Reed LA. 1976. Occurrence of pesticide residues in four streams draining different land use areas in Pennsylvania, 1969-1971. Pestic Monit J 10:101-110.

4. Munn MD, Gruber SJ. 1997. The relationship between land use and organochlorine compounds in streambed sediment and fish in the Central Columbia Plateau, Washington and Idaho, USA. Environ Toxicol Chem 16:1877-1887.

5. Cairns JC, Niederlehnier BR. 1995. Predictive ecotoxicology. In Hoffman DJ, Rattner BA, Burton GA, Cairns J, eds, Handbook of Ecotoxicology. CRC, Boca Raton, FL, USA, pp 667-680.

6. Stevenson RJ. 1997. Resource thresholds and stream ecosystem sustainability. J N Am Benthol Soc 16:410-424.

7. U.S. Environmental Protection Agency. 1992. National study of chemical residues in fish, Vol 1 EPA 823-R-92-008a. Washington, DC.

8. Schmitt CJ, Zajicek JL, Peterman PH. 1990. National contaminant biomonitoring program: Residues of organochlorine chemicals in U.S. freshwater fish, 1976-1984. Arch Environ Contam Toxicol 19:748-781.

9. Simonich SL, Hites RA. 1995. Global distribution of persistent organochlorine compounds. Science 269:1851-1854.

10. Nimmo DR. 1985. Pesticides. In Rand GM, Petrocelli SR, eds, 
Fundamentals of Aquatic Toxicology. Hemisphere, New York, NY, USA, pp 335-373.

11. Moriarty F. 1988. Ecotoxicology, 2nd ed. Academic, New York, NY, USA.

12. Miller MA. 1993. Maternal transfer of organochlorine compounds in salmonines to their eggs. Can J Fish Aquat Sci 50:1405-1413.

13. Leatherland J. 1992. Endocrine and reproductive function in Great Lakes salmon. In Colborn T, Clement C, eds, Chemically Induced Alterations in Sexual and Functional Development: The Wildlife/ Human Connection. Princeton Scientific, Princeton, NJ, USA, pp $145-192$.

14. Kloepper-Sams PJ, Swanson SM, Marchant T, Schryer R, Owens JW. 1994. Exposure of fish to biologically treated bleached-kraft effluent. 1. Biochemical, physiological and pathological assessment of Rocky Mountain whitefish (Prosopium williamsoni) and longnose sucker (Catostomus catostomus). Environ Toxicol Chem 13:1469-1482.

15. Hontela A, Dumont P, Duclos D, Fortin R. 1995. Endocrine and metabolic dysfunction in yellow perch, Perca flavescens, exposed to organic contaminants and heavy metals in the St. Lawrence River. Environ Toxicol Chem 14:725-731.

16. Goodbred SL, Gilliom RJ, Gross TS, Denslow NP, Bryant WL, Schoeb TR. 1997. Reconnaissance of 17ß-estradiol, 11-ketotestosterone, vitellogenin, and gonad histopathology in common carp of United States streams: Potential for contaminant-induced endocrine disruption. Open File Report 96-627. U.S. Geological Society, Sacramento, CA.

17. Arkoosh MR, Casillas E, Huffman P, Clemons E, Evered J, Stein JE, Varanasi U. 1998. Increased susceptibility of juvenile chinook salmon form a contaminated estuary to Vibrio anguillarum. Trans Am Fish Soc 127:360-374.

18. Altman B, Henson CM, Waite IR. 1997. Summary of information on aquatic biota and their habitats in the Willamette Basin, Oregon, through 1995. Water-Resources Investigations Report 974023. U.S. Geological Survey, Portland, OR.

19. Black RW, Silkey M. 1998. Water-quality assessment of the Puget Sound Basin, Washington: Summary of stream biological data through 1995 Water-Resources Investigations Report 97-4164. U.S. Geological Survey, Tacoma, WA.

20. Omernik JM, Gallant AL. 1986. Ecoregions of the Pacific Northwest. EPA 600/3-86/033. U.S. Environmental Protection Agency, Corvallis, OR.

21. Staubitz WW, Bortleson GC, Semans SD, Tesoriero AJ, Black RW. 1997. Water-quality assessment of the Puget Sound Basin, Washington: Environmental setting and its implications for water quality and aquatic biota. Water-Resources Investigations Report 97-4013. U.S. Geological Survey, Tacoma, WA.

22. U.S. Geological Survey. 1990. Land use and land cover digital data from 1:250,000- and 100,000-scale maps. Data Users Guide 4. Reston, VA.

23. Hitt KJ. 1994. Refining 1970's land-use data with 1990 population data to indicate new residential development. Water-Resources Investigations Report 94-4250. U.S. Geological Survey, Reston, VA.

24. MacCoy D, Black RW. 1998. Organic compounds and trace elements in fresh water streambed sediment and fish from the Puget Sound Basin. Fact Sheet 105-98. U.S. Geological Survey, Tacoma, WA.

25. Brown LR. 1991. Differences in habitat choice and behavior among three species of sculpin (Cottus) in artificial stream channels. Copeia 3:810-819.

26. Brown LR, Matern SA, Moyle PB. 1995. Comparative ecology of prickly sculpin, Cottus asper, and coastrange sculpin, C. aleuticus, in the Eel River, California. Environ Biol Fishes 42:329_ 343.

27. Crawford JK, Luoma SN. 1993. Guidelines for studies of con- taminants in biological tissues for the National Water Quality Assessment Program. Open-File Report 94-494. U.S. Geological Survey, Lemoyne, PA.

28. Shelton LR, Capel PD. 1994. Guidelines for collecting and processing samples of streambed sediment for analysis of trance elements and organic contaminants for the National Water Quality Assessment Program. Open-File Report 94-458. U.S. Geological Survey, Sacramento, CA.

29. Code of Federal Regulations 40. 1992. Guidelines establishing test procedures for the analysis of pollutants. U.S. Government Printing Office, Washington, DC, pp 565-567.

30. Foreman WT, Connor BF, Furlong ET, Vaught DG, Merten LM. 1995. Methods of analysis by the U.S. Geological Survey National Water Quality Laboratory: Determination of organochlorine pesticides and polychlorinated biphenyls in bottom sediment by dual capillary-column gas chromatography with electron capture detection. Open-File Report 95-140. U.S. Geological Survey, Denver, CO.

31. Leiker TJ, Madsen JE, Deacon JR, Foreman WT. 1995. Methods of analysis by the U.S. Geological Survey National Water Quality Laboratory: Determination of chlorinated pesticides in aquatic tissue by dual capillary-column gas chromatography with electron capture detection. Open-File Report 94. U.S. Geological Survey, Denver, $\mathrm{CO}$

32. Reckhow KH, Black RW, Stockton TB Jr, Vogt JD, Wood JG. 1987. Empirical models of fish response to lake acidification. Can J Fish Aquat Sci 44:1432-1442.

33. Tesoriero AJ, Voss FD. 1997. Predicting the probability of elevated nitrate concentrations in the Puget Sound Basin: Implications for aquifer susceptibility and vulnerability. Ground Water 35:1029-1039.

34. Hosmer DW, Lemeshow S. 1989. Applied Logistic Regression. John Wiley \& Sons, New York, NY, USA.

35. Helsel DR, Hirsch RM. 1992. Statistical Methods in Water Resources. Elsevier, New York, NY, USA.

36. Statistical Product and Service Solutions. 1997. SYSTAT ${ }^{\circledR} 7.0-$ New Statistics. Chicago, IL, USA.

37. Nagelkerke NJD. 1991. A note on a general definition of the coefficient of determination. Biometrika 78:691-692.

38. Wentz DA, Waite IR, Rinella FA. 1998. Comparison of streambed sediment and aquatic biota as media for characterizing trace elements and organochlorine compounds in the Willamette Basin, Oregon. Environ Monit Assess 51:673-693.

39. Morris RL, Johnson LG, Ebbert DW. 1972. Pesticides and heavy metals in the aquatic environment. Health Lab Sci 9:145.

40. Lyman WJ. 1995. Transport and transforming processes. In Rand GM, ed, Fundamentals of Aquatic Toxicology: Effects, Environmental Fate and Risk Assessment, 2nd ed. Taylor \& Francis, Washington, DC, USA, pp 449-492.

41. Spacie A, McCarty LS, Rand GM. 1995. Bioaccumulation and bioavailability in multiphase systems. In Rand GM, ed, Fundamentals of Aquatic Toxicology: Effects, Environmental Fate and Risk Assessment, 2nd ed. Taylor \& Francis, Washington, DC, USA, pp 493-522.

42. Johnson A, Norton D, Yake B. 1988. Persistence of DDT in the Yakima River drainage, Washington. Arch Environ Contam Toxicol 17:289-297.

43. Saiki MK, Schmitt CJ. 1986. Organochlorine chemical residues in bluegills and common carp from irrigated San Joaquin Valley Floor, California. Arch Environ Contam Toxicol 15:357-366.

44. Gilliom RJ, Clifton DG. 1990. Organochlorine pesticide residues in bed sediments of the San Joaquin River, California. Water Resour Bull 26:11-24.

45. Majewski MS, Capel PD. 1995. Pesticides in the Atmosphere: Distribution, Trends, and Governing Factors. Ann Arbor Press, Chelsea, MI, USA. 